\author{
Research Article \\ www.ijrap.net
}

\title{
QUANTITATIVE EVALUATION OF INDUCED MACROMUTANTS IN FENNEL (FOENICULUM VULGARE MILL.)
}

Paul Rita ${ }^{1 *}$ and Datta K. Animesh ${ }^{2}$

${ }^{1}$ Assistant Professor, Department of Botany, Charuchandra College, Kolkata, West Bengal, India

${ }^{2}$ Professor, Department of Botany, Cytogenetics and Plant Breeding Section, University of Kalyani, Kalyani, West Bengal, India

Received on: 14/11/16 Revised on: 14/12/16 Accepted on: 21/12/16

\author{
*Corresponding author \\ E-mail: ritapaul2000@gmail.com
}

DOI: $10.7897 / 2277-4343.076250$

\section{ABSTRACT}

Macromutants namely, thick stem, slender stem, pigmented stem, dwarf, elongated pinnae, narrow pinnae and early flowering are screened at $\mathrm{M}_{2}$ generation (total plants screened - 1575) following exposure of dry seeds (moisture content - 9.3\%) of fennel (Foeniculum vulgare Mill., Family: Umbelliferae) to different doses/concentrations of $\gamma$-irradiations and EMS. Selfed lines of the mutants are evaluated in $\mathrm{M}_{6}$ generation in comparison to control considering eight phenotypic traits (plant height, number of primary branches/plant, total branches/plant, number of compound umbels/plant, number of umbels/plant, number of umbellets of first inflorescence, seed yield and harvest index). Statistical test (Duncan's test at 5\% level of significance) reveal that thick stem mutant is a promising mutant for direct use; while, the rest may be exploited by efficient breeding.

Keywords: Fennel, Macromutants, Traits, Evaluation

\section{INTRODUCTION}

Fennel (Foeniculum vulgare Mill., Family: Umbelliferae; $2 n=22$ ) is one of the widespread economically very important seed spices of India. Besides using it as spice in culinary art, it is also used in cosmetic and pharmaceutical products ${ }^{1}$. The essential oil of fennel has a valuable antioxidant ${ }^{2-6}$, antimicrobial $^{4-9}, \quad$ antispasmodic $^{10}$, anticancerous ${ }^{11-13}$, antidiabetic $^{14}$, antithrombotic ${ }^{15}$, hepatoprotective ${ }^{16}$, even memory enhancing ${ }^{17}$ activity. The diuretic, anti-inflammatory ${ }^{18}$, analgesic ${ }^{18}$ effects of fennel are well known for centuries in folk medicine. The increasing commercial value of fennel in both National and International market necessitates its sustainable cultivation for increasing yield and value added products. With the view to it, the methodology of induced mutagenesis (EMS and $\gamma$-irradiations) has been adopted. Screened macromutant plant types are analyzed at $\mathrm{M}_{6}$ generation in relation to control to detect significant variations, if any, aiding to efficient breeding and crop improvement relating to yield and bioactive compounds.

\section{MATERIAL AND METHODS}

Phenotypic mutations were induced following exposure of dry seeds (moisture content $-9.3 \%)$ to $\gamma$-irradiations $(20,40,80$ and $100 \mathrm{~Gy})$ and EMS $(0.25 \%, 0.50 \%$ and $1.0 \% ; 2 \mathrm{~h}$ and $4 \mathrm{~h})$ treatments. Seven macromutants (thick stem - TS, slender stem SS, pigmented stem - PS, dwarf - Dw, elongated pinnae - EP, narrow pinnae - NP and early flowering - EF) were screened (total plants screened - 1575) at $\mathrm{M}_{2}$ generation and after maintaining for five generations are compared to control (C) for yield and yield related traits (plant height, number of primary branches/plant, total branches/plant, number of compound umbels/plant, number of umbels/plant, number of umbellets of first inflorescence, seed yield and harvest index) in $\mathrm{M}_{6}$ generation. The plant types are grown in randomized block design in 3 replications (spacing of $25 \mathrm{~cm}$ between lines and 10 $\mathrm{cm}$ between plants).

Five plants are randomly selected from each replication and a total of 15 plants are assessed for each plant type. Duncan's test ${ }^{19}$ is computed ( $5 \%$ level of significance) for each parameter to assess significant variation between/among the plant types. Homogenous treatment means are assessed following Duncan's test. Alphabets are used corresponding to each mean to denote the magnitude of performance of each trait in each plant type; the alphabets are arranged in descending order to indicate the gradation of superiority. Similar alphabets represent homogenous plant types and the more the common alphabets in the plant types, the less the non-significant differences between them.

\section{RESULTS AND DISCUSSION}

Results indicate (Table 1) that there are significant variations among plant types for the traits excepting number of primary branches per plant. Thick stem mutant shows significant enhancement in number of umbellets of the first formed inflorescence than control. In this mutant type total branches/plant, number of compound umbels/plant, number of umbels/plant and seed yield also exhibit superiority over control. Elongated pinnae mutant also manifests betterment in plant height trait than control. From the results obtained it can be inferred that none of the mutants have exhibited superiority over respective control for all the traits under study but a few of them have shown betterment in some traits.

Research aiming to improvement through induced mutagenesis is rare in seed spices. Ramkrishna ${ }^{20}$ using gamma irradiations and chemical mutagens (EMS and Sodium Azide) developed some superior $\mathrm{M}_{2}$ progenies in fennel with higher yield than control; Mostafa and Abou Alhamd ${ }^{21}$ produced two superior mutants than control in respect of salt tolerance using dimethyl 
sulphate (DMS). In the present investigation among the entire mutants thick stem mutant is the most promising plant type in comparison to control and offer scope of direct selection; while, breeding endeavor followed by selection may be recommended for the rest plant types.
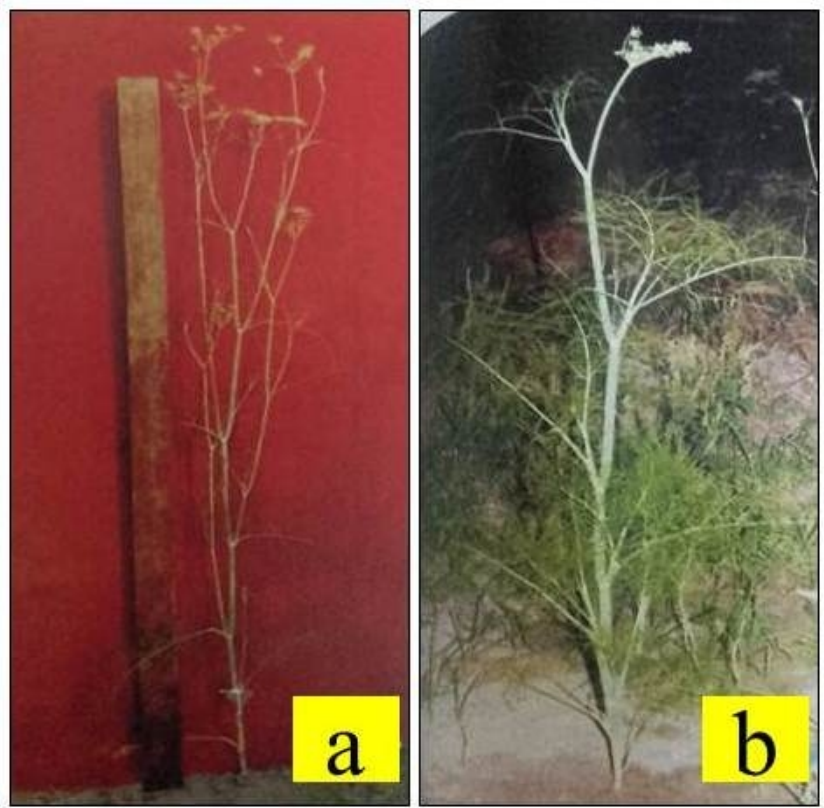

Figure 1: a. Control (stem diameter at base $-5 \mathrm{~mm}$ ), b. Thick stem mutant (diameter - $11 \mathrm{~mm})$

Table 1: Mean of eight parameters in control and macromutants of fennel

\begin{tabular}{|c|c|c|c|c|c|c|c|c|}
\hline \multirow[t]{2}{*}{ Quantitative traits } & \multicolumn{8}{|c|}{ Plant types } \\
\hline & $\mathrm{C}$ & TS & SS & PS & Dw & EP & NP & $\mathrm{EF}$ \\
\hline Plant height $(\mathrm{cm})$ & $\begin{array}{c}84.0 \mathrm{ab} \\
\pm \\
2.7\end{array}$ & $\begin{array}{c}87.7 \mathrm{ab} \\
\pm \\
6.6\end{array}$ & $\begin{array}{c}64.0 \mathrm{~cd} \\
\pm \\
2.9\end{array}$ & $\begin{array}{c}51.2 \mathrm{de} \\
\pm \\
1.2\end{array}$ & $\begin{array}{c}44.5 \mathrm{e} \\
\pm \\
1.0\end{array}$ & $\begin{array}{c}96.0 \mathrm{a} \\
\pm \\
6.7\end{array}$ & $\begin{array}{c}56.4 \mathrm{de} \\
\pm \\
3.1\end{array}$ & $\begin{array}{c}73.3 \mathrm{bc} \\
\pm \\
5.0\end{array}$ \\
\hline $\begin{array}{l}\text { *No. of primary } \\
\text { branches/plant }\end{array}$ & $\begin{array}{c}6.4 \\
\pm \\
0.4\end{array}$ & $\begin{array}{c}6.0 \\
\pm \\
1.0\end{array}$ & $\begin{array}{c}5.5 \\
\pm \\
0.3\end{array}$ & $\begin{array}{c}5.0 \\
\pm \\
0.6\end{array}$ & $\begin{array}{c}5.7 \\
\pm \\
1.5\end{array}$ & $\begin{array}{c}5.3 \\
\pm \\
0.3\end{array}$ & $\begin{array}{c}5.4 \\
\pm \\
0.2\end{array}$ & $\begin{array}{c}4.7 \\
\pm \\
0.3\end{array}$ \\
\hline $\begin{array}{c}\text { Total } \\
\text { branches/plant }\end{array}$ & $\begin{array}{c}25.4 \mathrm{ab} \\
\pm \\
2.5\end{array}$ & $\begin{array}{c}32.7 \mathrm{a} \\
\pm \\
13.0\end{array}$ & $\begin{array}{c}19.0 \mathrm{bc} \\
\pm \\
2.4\end{array}$ & $\begin{array}{c}11.3 \mathrm{c} \\
\pm \\
0.7\end{array}$ & $\begin{array}{c}17.0 \mathrm{bc} \\
\pm \\
5.5\end{array}$ & $\begin{array}{c}25.5 \mathrm{ab} \\
\pm \\
3.5\end{array}$ & $\begin{array}{c}15.2 \mathrm{bc} \\
\pm \\
0.6\end{array}$ & $\begin{array}{c}18.2 \mathrm{bc} \\
\pm \\
2.2\end{array}$ \\
\hline $\begin{array}{l}\text { No. of compound } \\
\text { umbels/plant }\end{array}$ & $\begin{array}{c}22.6 \mathrm{ab} \\
\pm \\
3.0\end{array}$ & $\begin{array}{c}25.3 \mathrm{a} \\
\pm \\
9.4\end{array}$ & $\begin{array}{c}17.0 \mathrm{abc} \\
\pm \\
2.5\end{array}$ & $\begin{array}{c}10.0 \mathrm{c} \\
\pm \\
0.6 \\
\end{array}$ & $\begin{array}{c}13.0 \mathrm{bc} \\
\pm \\
4.4\end{array}$ & $\begin{array}{c}16.3 \mathrm{abc} \\
\pm \\
2.4\end{array}$ & $\begin{array}{c}12.6 \mathrm{bc} \\
\pm \\
1.2\end{array}$ & $\begin{array}{c}13.5 \mathrm{bc} \\
\pm \\
1.8\end{array}$ \\
\hline $\begin{array}{c}\text { No. of } \\
\text { umbels/plant }\end{array}$ & $\begin{array}{c}154.8 \mathrm{ab} \\
\pm \\
19.1\end{array}$ & $\begin{array}{c}203.0 \mathrm{a} \\
\pm \\
74.2\end{array}$ & $\begin{array}{c}86.8 \text { bc } \\
\pm \\
11.6\end{array}$ & $\begin{array}{c}48.0 \mathrm{c} \\
\pm \\
1.5 \\
\end{array}$ & $\begin{array}{c}63.0 \mathrm{c} \\
\pm \\
20.1\end{array}$ & $\begin{array}{c}144.3 \mathrm{ab} \\
\pm \\
12.0\end{array}$ & $\begin{array}{c}66.2 \mathrm{c} \\
\pm \\
7.9\end{array}$ & $\begin{array}{c}108.3 \mathrm{bc} \\
\pm \\
13.5\end{array}$ \\
\hline $\begin{array}{c}\text { No. of umbellets } \\
\text { of first } \\
\text { inflorescence }\end{array}$ & $\begin{array}{c}27.4 \mathrm{~b} \\
\pm \\
6.8\end{array}$ & $\begin{array}{c}83.3 \mathrm{a} \\
\pm \\
18.3\end{array}$ & $\begin{array}{c}25.0 \mathrm{~b} \\
\pm \\
4.7\end{array}$ & $\begin{array}{c}37.7 \mathrm{~b} \\
\pm \\
4.7\end{array}$ & $\begin{array}{l}30.7 \mathrm{~b} \\
\pm \\
10.2\end{array}$ & $\begin{array}{c}47.5 \mathrm{~b} \\
\pm \\
9.9\end{array}$ & $\begin{array}{c}28.2 \mathrm{~b} \\
\pm \\
5.2\end{array}$ & $\begin{array}{c}38.3 \mathrm{~b} \\
\pm \\
5.3\end{array}$ \\
\hline Seed yield (gm) & $\begin{array}{c}2.17 \mathrm{ab} \\
\pm \\
0.5\end{array}$ & $\begin{array}{c}2.29 \mathrm{a} \\
\pm \\
0.9\end{array}$ & $\begin{array}{c}1.02 \mathrm{bcd} \\
\pm \\
0.1\end{array}$ & $\begin{array}{c}0.90 \mathrm{~cd} \\
\pm \\
0.01\end{array}$ & $\begin{array}{c}0.24 \mathrm{~d} \\
\pm \\
0.1\end{array}$ & $\begin{array}{c}1.62 \mathrm{abc} \\
\pm \\
0.4\end{array}$ & $\begin{array}{c}0.74 \mathrm{~cd} \\
\pm \\
0.1\end{array}$ & $\begin{array}{c}1.22 \mathrm{abcd} \\
\pm \\
0.2\end{array}$ \\
\hline Harvest index $(\%)$ & $\begin{array}{c}29.3 \mathrm{a} \\
\pm \\
1.7\end{array}$ & $\begin{array}{c}18.3 \mathrm{ab} \\
\pm \\
6.2\end{array}$ & $\begin{array}{c}20.4 \mathrm{ab} \\
\pm \\
1.1 \\
\end{array}$ & $\begin{array}{c}24.0 \mathrm{ab} \\
\pm \\
0.2\end{array}$ & $\begin{array}{c}11.4 \mathrm{~b} \\
\pm \\
4.2 \\
\end{array}$ & $\begin{array}{c}18.4 \mathrm{ab} \\
\pm \\
3.8\end{array}$ & $\begin{array}{c}19.5 \mathrm{ab} \\
\pm \\
2.3\end{array}$ & $\begin{array}{c}21.5 \mathrm{ab} \\
\pm \\
3.8\end{array}$ \\
\hline
\end{tabular}

C- control, TS- thick stem, SS- slender stem, PS- pigmented stem, Dw- dwarf, EP- elongated pinnae, NP- narrow pinnae and EF- early flowering. *non-significant variations among the plant types.

\section{CONCLUSION}

The aim to raise desirable plant type mutants through induced mutagenesis has been accomplished to some extent in this spice. The thick stem mutant evolved seems to be in the direction of the objective underlined and corresponds closely with the ideotype been looked for in the crops. This plant type can be selected for further efficient breeding programme.

\section{REFERENCES}

1. Piccaglia R, Marotti M. Characterization of Some Italian Types of Wild Fennel (Foeniculum vulgare Mill.) J Agric Food Chem 2001; 49:239-44.

2. Faudale M, Viladomat F, Bastida J, Poli F, Codina C. Antioxidant activity and phenolic composition of wild, edible and medicinal fennel from different Mediterranean countries. J Agric Food Chem 2008; 56(6):1912-20. 
3. Oktay M, G"ulc,in I, K"ufrevioglu OI. Determination of in vitro antioxidant activity of fennel (Foeniculum vulgare) seed extracts. LWT- Food Sci Technol 2003; 36(2):263-71.

4. Anwar F, Ali M, Hussain AI, Shahid M. Antioxidant and antimicrobial activities of essential oil and extracts of fennel (Foeniculum vulgare Mill.) seeds from Pakistan. Flavour Frag J 2009; 24(4):170-6.

5. Shahat AA, Ibrahim AY, Hendawy SF, Omer EA, Hammouda FM, Abdel-Rahman FH et al. Chemical composition, antimicrobial and antioxidant activities of essential oils from organically cultivated fennel cultivars. Molecules 2011; 16:1366- 77.

6. Singh G, Maurya S, de Lampasona MP, Catalan C. Chemical constituents, antifungal and antioxidative potential of Foeniculum vulgare volatile oil and its acetone extract. Food Control 2006; 17:745-52.

7. Gulfraz M, Mehmood S, Minhas N, Jabeen N, Kausar R, Jabeen $\mathrm{K}$ et al. Composition and antimicrobial properties of essential oil of Foeniculum vulgare. African J Biotechnol 2008; 7(24):4364-8.

8. Abed KF. Antimicrobial activity of essential oils of some medicinal plants from Saudi Arabia. Saudi J Biol Sci 2007; 14:53-60.

9. Mohsenzadeh M. Evaluation of antibacterial activity of selected Iranian essential oils against Staphylococcus aureus and Escherichia coli in nutrient broth medium. Pak J Biol Sci 2007; 10:3693-7.

10. Saini N, Singh G.K., Nagori B.P. Spasmolytic potential of some medicinal plants belonging to family Umbelliferae: A review. Int. J. Res. Ayurveda Pharm. 2014;5(1):74-83 http://dx.doi.org/10.7897/2277-4343.05116

11. Anand P, Kunnumakara A, Sundaram C, Harikumar K, Tharakan S, Lai $\mathrm{O}$ et al. Cancer is a preventable disease that requires major lifestyle changes. Pharmaceut Res 2008; 25:2097-116.

12. Pradhan M, Sribhuwaneswari S, Karthikeyan D, Minz S, Sure P, Chandu AN et al. In-vitro cytoprotection activity of Foeniculum vulgare and Helicteres isora in cultured human blood lymphocytes and antitumour activity against B16F10 melanoma cell line. Res J Pharm Technol 2008; 1(4):450-2.
13. Mohamad RH, El-Bastawesy AM, Abdel-Monem MG, Noor AM, Al-Mehdar HAR, Sharawy SM et al. Antioxidant and Anticarcinogenic Effects of Methanolic Extract and Volatile Oil of Fennel Seeds (Foeniculum vulgare). J Med Food 2011; 14(9):986-1001.

14. El-Soud NA, El-Laithy N, El-Saeed G, Wahby MS, Khalil M, Morsy F et al. Antidiabetic activities of Foeniculum vulgare Mill. essential oil in streptozotocin-induced diabetic rats. Macedonian J Med Sci 2011; 4(2):139-46.

15. Tognolini M, Ballabeni V, Bertoni S, Bruni R, Impicciatore M, Barocelli E. Protective effect of Foeniculum vulgare essential oil and anethole in an experimental model of thrombosis. Pharmacol Res 2007; 56:254-60.

16. Özbek H, Uğraş S, Dülger H, Bayram I, Tuncer I, Öztürk G et al. Hepatoprotective effect of Foeniculum vulgare essential oil. Fitoterapia 2003; 74(3):317-9.

17. Koppula S, Kumar H. Foeniculum vulgare Mill. (Umbelliferae) attenuates stress and improves memory in wister rats. Trop J Pharm Res 2013; 12(4):553-8.

18. Choi E, Hwang J. Antiinflammatory analgesic and antioxidant activities of the fruit of Foeniculum vulgare. Fitoterapia 2004; 75:557-65.

19. Duncan DB. Multiple range and multiple F tests. Biometrics 1955; II:1-42.

20. Ramkrishna K. Mutation breeding in seed spices. Proc. of Int. symp. on induced mutations in plants (ISIM). Joint FAO/IAEA Division of Nuclear Techniques in Food and Agriculture, Vienna (Austria) 2008; p.167.

21. Mostafa GG, Abou Alhamd MF. Induction of Salt Tolerant Mutants of Foeniculum vulgare by Dimethyl Sulphate and Their Identification Using Protein Pattern and ISSR Markers. Alex J Agric Res 2015; 60(2):95-109.

\section{Cite this article as:}

Paul Rita and Datta K. Animesh. Quantitative evaluation of induced macromutants in Fennel (Foeniculum vulgare Mill.). Int. J. Res. Ayurveda Pharm. Nov - Dec 2016;7(6):107-109 http://dx.doi.org/10.7897/2277-4343.076250

Disclaimer: IJRAP is solely owned by Moksha Publishing House - A non-profit publishing house, dedicated to publish quality research, while every effort has been taken to verify the accuracy of the content published in our Journal. IJRAP cannot accept any responsibility or liability for the site content and articles published. The views expressed in articles by our contributing authors are not necessarily those of IJRAP editor or editorial board members. 